\title{
AKAR-AKAR LEGAL INTOLERANSI DAN DISKRIMINASI DI INDONESIA
}

Luthfi Assyaukanie

Dosen Universitas Paramadina dan Peneliti SMRC, Jakarta.

\begin{abstract}
Abstrak
Artikel ini mengeksplorasi sebab-sebab yang lebih mendalam dari intoleransi dan diskriminasi yang terjadi di Indonesia akhir-akhir ini. Ia melampaui penjelasan-penjelasan yang umumnya dikemukakan para penulis selama ini, seperti situasi politik, kondisi ekonomi, struktur sosial, dan karakter budaya. Dalam artikel ini, akar-akar intoleransi dan diskriminasi bisa ditelusuri ke lanskap legal Indonesia berupa landasan negara, pasal-pasal konstitusional, undang-undang, dan aturan-aturan yang berlaku.

Kata Kunci : Intoleransi, konservatisme, diskriminasi, Pancasila, Orde Lama, Orde Baru
\end{abstract}

Temuan beberapa lembaga survey tentang meningkatnya jumlah intoleransi di Indonesia memiliki kaitan erat dengan gelombang konservatisme yang melanda Indonesia sejak beberapa tahun terakhir. ${ }^{33}$ Intoleransi tidak akan tumbuh jika tak ada lahan yang menopangnya. Konservatisme adalah lahan di mana ekstrimisme, radikalisme, intoleransi, terorisme, dan beragam jenis kekerasan atas nama agama belakangan tumbuh subur. Konservatisme agama telah ada sejak lama, jauh sebelum Indonesia menjalani transisi demokrasi pada penghujung tahun 1990an. Tapi, jumlahnya tak sebanyak dan tak seekspresif sekarang. Kaum konservatif Islam telah ada sejak sebelum kemerdekaan Indonesia. Tapi, kiprah mereka di ruang-ruang publik secara massif baru terjadi di era demokrasi. ${ }^{34}$

33 Survey LSI (Lembaga Survey Indonesia) yang dirilis pada September 2018, menunjukkan bahwa lebih dari $50 \%$ penduduk Indonesia bersikap intoleran pada agama lain. Survey PPIM yang dirilis pada 16 Oktober 2018 menemukan bahwa mayoritas guru Muslim(63\%) di sekolah-sekolah di Indonesia punya pandangan intoleran terhadap agama dan keyakinan berbeda.

34 Bruinessen, Martin van. Contemporary Developments in Indonesian Islam: Explaining the "Conservative Turn." Institute of Southeast Asian Studies, 2013. 
Para sarjana menggunakan istilah berbeda-beda untuk merujuk fenomena yang sama. Ada yang menggunakan istilah "fundamentalisme," "puritanisme," "revivalisme," "ekstrimisme," "radikalisme," dan istilah-istilah lain yang mengacu pada kebangkitan Islam. Untuk menyederhanakannya, dalam tulisan ini, saya menggunakan "konservatisme" sebagai kata generik untuk memayungi semua gejala kebangkitan Islam. Berbagai peristiwa sosial-keagamaan yang terjadi di Indonesia, dari intoleransi, kekerasan, diskriminasi, hingga terorisme, berawal atau terkait langsung maupun tidak langsung dengan konservatisme.

Konservatisme adalah sebuah sikap keagamaan yang menekankan pentingnya tradisi dan nilai-nilai lama. Agama pada dasarnya bersifat konservatif. Karenanya, kaum konservatif umumnya menentang gerakan-gerakan reformis yang berusaha memperbaharui pemahaman agama. Di Indonesia, kaum konservatif bisa ditemukan di lembaga-lembaga tradisional, seperti Nahdlatul Ulama (NU) atau juga lembaga-lembaga modernis seperti Muhammadiyah. Kaum konservatif juga bisa dijumpai di kalangan kelas menengah kota yang baru mengenal Islam (new-born Muslim). Sebelum era demokrasi, kaum konservatif umumnya tidak menyuarakan aspirasi keagamaan atau politik mereka di ruang-ruang publik. Pada masa Soeharto, kelompok-kelompok konservatif tak bisa dengan leluasa mengekspresikan keyakinan dan pandangan keagamaan mereka. Pemerintah Orde Baru melakukan kebijakan represif terhadap Islam politik.

Ada banyak kajian tentang mengapa dan bagaimana konservatisme Islam di Indonesia mengalami kebangkitan. Sebagian sarjana mengaitkannya dengan situasi kebebasan yang terjadi sejak 1998. ${ }^{35}$ Jatuhnya Soeharto menciptakan babak baru bagi kehidupan politik yang lebih terbuka dan bebas. Orang tidak lagi takut mengekspresikan pandangan keagamaan dan politiknya. Organisasi massa dan partai politik diberi kebebasan untuk memperjuangkan aspirasi mereka. Bukan hanya kelompok-kelompok sekular yang memanfaatkan situasi ini, tapi kelompok-kelompok keagamaan juga menjadi bagianaktif dalam mengisi ruang-ruang kebebasan yang tersedia. Dari sini, muncullah organisasi-organisasi keagamaan dan partai-partai politik yang mengusung aspirasi kaum konservatif, seperti perubahan konstitusi, pelaksanaan syariat Islam, dan produksi aturanaturan (Perda) yang Islami. Sebagian organisasi ini menggunakan cara-cara demokratis untuk memperjuangkan aspirasi mereka. Sebagian yang lain, seperti Front Pembela Islam (FPI) menggunakan cara-cara kekerasan dan pemaksaan.

35 Lihat misalnya, Azra, Azyumardi. Indonesia, Islam, and Democracy: Dynamics in a Global Context. Equinox Publishing, 2006; Mujani, Saiful. Muslim Demokrat: Islam, Budaya Demokrasi, dan Partisipasi Politik di Indonesia Pasca Orde Baru. Gramedia Pustaka Utama, 2007; Fealy, Greg, and Sally White. Expressing Islam: Religious Life and Politics in Indonesia. Institute of Southeast Asian Studies, 2008. 
Sebagian sarjana lain mengaitkan kebangkitan konservatisme di Indonesia dengan pertumbuhan ekonomi dan naiknya kelas menengah Muslim. ${ }^{36}$ Mereka berargumen bahwa kebangkitan Islam sudah dimulai sejak awal tahun 1990an, ketika Presiden Soeharto memasuki periode ke-5 pemerintahannya. Dekade 1990an dicatat sebagai era kedekatan antara Islam dan Orde Baru. Di periode ini, Seoharto mengeluarkan sejumlah kebijakan yang bersahabat dengan umat Islam, seperti pendirian Bank Muamalat, pendirian ICMI, dan pembangunan 1000 masjid di bawah naungan Yayasan Amal Bakti Muslim Pancasila. Kebijakan pro-Islam Soeharto ini merupakan respon terhadap bangkitnya kelas menengah Muslim kota yang jumlahnya semakin besar. Hefner menyebut mereka sebagai perwakilan "Civil Islam," yakni kelompok yang berusaha menghadirkan etos Islam dengan cara-cara yang modern dan beradab.

Sebagian sarjana lain mengaitkan kebangkitan konservatisme dengan konteks kesejarahan Indonesia, khususnya menyangkut hubungan Islam dan negara ${ }^{37}$ Seperti pernah diramalkan Harry J. Benda, sarjana Amerika Serikat, Islam memiliki karakter ekspansif dan cenderung memperluas pengaruhnya pada level masyarakat dan negara. Menurutnya, sejarah Indonesia adalah "perluasan peradaban santri." 38 Yang dimaksud dengan "santri" bukan hanya para pelajar pesantren di desa-desa. Tapi juga, kaum Muslim siapa saja yang taat pada nilai-nilai agamanya. Dengan kata lain, santri adalah kaum konservatif yang kita bicarakan hari-hari ini. Ramalan Benda terbukti benar. Sejarah Indonesia adalah sejarah Islamisasi, baik Islamisasi dalam pengertian pengkonversian orang-orang non-Muslim menjadi Islam maupun dalam pengertian pengislaman perilaku dan aspek-aspek kehidupan kaum Muslim, baik pada level masyarakat maupun negara.

Saya sepenuhnya sepakat dengan penjelasan di atas. Menurut saya, penjelasan itu bukannya untuk saling menegasikan, tapi justru saling melengkapi. Kebangkitan Islam Indonesia terkait erat dengan masalah transisi politik, ekonomi, dan juga terkait dengan latar belakang sosio-historis. Yang menjadi pertanyaan sesungguhnya adalah mengapa perluasan peradaban santri berjalan cukup mulus? Bahkan pada era Soeharto yang dikenal represif, Islamisasi

36 Lihat misalnya, Hefner, Robert W. Civil Islam: Muslims and Democratization in Indonesia. Princeton University Press, 2011; Burhanudin, Jajat, and Kees van Dijk. Islam in Indonesia: Contrasting Images and Interpretations. Amsterdam University Press, 2013.

37 Kersten, Carool. Islam in Indonesia: The Contest for Society, Ideas and Values. Oxford University Press, 2015; Platzdasch, Bernhard. Islamism in Indonesia: Politics in the Emerging Democracy. Institute of Southeast Asian Studies, 2009; Mietzner, Marcus. Military Politics, Islam, and the State in Indonesia: From Turbulent Transition to Democratic Consolidation. Institute of Southeast Asian Studies, 2009.

38 Benda, Harry Jindrich. The Crescent and the Rising Sun: Indonesian Islam Under the Japanese Occupation, $1942-$ 1945. Institute of Pacific Relations, New York, 1958, h. 14. 
berjalan cukup lancar. Kebijakan keagamaan Soeharto, seperti aturan pembatasan agama resmi, penguatan departemen agama, dan pembangunan institusi-institusi Islam, menjadi pelumas yang melancarkan ekpansi peradaban santri itu. Mengapa agama, Islam khususnya, memiliki dukungan yang sangat kuat untuk berkembang?

Artikel ini ingin menjawab pertanyaan-pertanyaan di atas dengan mengeksplorasi aspek-aspek yang lebih dalam dan fundamental dari apa yang selama ini kita baca. Saya memandang bahwa keberhasilan Islamisasi dengan segala dampaknya (radikalisme, terorisme, dll) memiliki akar yang jauh lebih dalam dan lebih kokoh dari sekadar aspek-aspek sosial, ekonomi, dan politik. Keberhasilan Islamisasi di Indonesia terkait erat dengan landasan fundamental negeri ini, berupa fondasi konstituional dan lanskap legal di mana Indonesia sebagai negara dan bangsa berdiri. Keberhasilan Islamisasi sangat ditentukan oleh karakter Indonesia sebagai negara yang memiliki konstitusi dan aturanaturan yang memungkinkan agama dan semangat keberagamaan tumbuh dengan subur.

Dalam artikel ini, saya akan membahas empat aspek yang menjadi akar-akar legal intoleransi dan diskriminasi di Indonesia. Karena keterbatasan ruang, saya tidak membahas aspek-aspek yang bersifat institusional di mana akar-akar legal ini dikembangkan dan dirawat begitu rupa sehingga memunculkan berbagai persoalan terkait agama dan politik seperti kita saksikan akhir-akhir ini.

\section{Tafsir Pancasila}

Perdebatan apakah Indonesia "negara sekular" atau "negara agama" telah ada sejak lama dan merupakan indikasi paling nyata tentang ketidakjelasan bentuk negara ini. Kaum sekular berusaha meyakinkan bahwa Indonesia dibangun di atas semangat keragaman yang pluralis dan menghargai setiap hak individu, terlepas dari keyakinan dan agamanya. Indonesia adalah negara "netral" yang memilih Pancasila sebagai dasarnya. Pancasila sendiri berisi prinsip-prinsip yang bisa menampung semua warga dari beragam latar belakang, baik yang beragama maupun tak beragama, yang beriman maupun tak beriman. Sementara kaum agamawan menganggap Indonesia adalah negara religius. Sejak sebelum kemerdekaan, kaum religius (diwakili oleh kelompok Islam) berusaha menjadikan Islam sebagai dasar negara. ${ }^{39}$ Perdebatan panjang dalam sidang-

39 Effendy, Bahtiar. Islam and the State in Indonesia. ISEAS Series on Islam. Singapore: Institute of Southeast Asian Studies, 2003 
sidang persiapan kemerdekaan antara kelompok nasionalis dan kelompok Islamis memunculkan Pancasila dengan susunan yang unik, di mana ketuhanan ditaruh sebagai sila pertama. Berbeda dari kaum sekular, kaum agamawan menganggap Pancasila sebagai landasan paling jelas bahwa Indonesia adalah negara religius.

Begitu ruwetnya perdebatan tentang bentuk negara Indonesia, presiden Abdurrahman Wahid pernah berseloroh bahwa Indonesia adalah "negara bukan-bukan.” ${ }^{40}$ Maksudnya, Indonesia bukan negara sekular dan bukan pula negara agama. Kedua-keduanya memiliki tempat dan kedua-duanya memiliki klaim yang sama. Pancasila adalah prinsip yang menampung semua keyakinan orang, baik yang religius (diwakili oleh sila pertama) maupun yang tak religius (diwakili oleh sila-sila lainnya). Siapa yang berhasil memenangkan tafsir terhadap Pancasila, merekalah yang akan menang dan mendominasi percakapan tentang karakter dan bentuk negara Indonesia. Siapa yang kalah, dialah yang akan menjadi korban. Dengan kata lain, Pancasila menyimpan masalah sejak awal ia diumumkan.

Sepanjang sejarah Indonesia merdeka, Pancasila menjadi alat perekat sekaligus alasan untuk berpisah dari negara kesatuan. Pada masa-masa awal kemerdekaan, Darul Islam, sebuah gerakan keagamaan yang tak puas dengan negara kesatuan Indonesia mengangkat senjata dan melakukan perlawanan kepada pemerintahan yang sah. ${ }^{41}$ Mereka menganggap Pancasila sebagai prinsip yang bertentangan dengan Islam. Pada masa Soeharto, kelompok-kelompok bawah tanah yang mengatasnamakan "perjuangan Islam” juga melakukan perlawanan, mengkritisi dan mengecam Pancasila sebagai "thagut" (iblis) yang harus dienyahkan dari republik. Bagi mereka, Pancasila bukanlah prinsip yang religius, tapi justru ajaran sekular dan anti-Islam. ${ }^{42}$ Bagi penguasa Orde Lama (Soekarno) dan Orde Baru (Soeharto), Pancasila bukan hanya alat untuk menyatukan bangsa, tapi juga instrumen untuk merawat dan melanggengkan kekuasaan mereka. Keduanya menjadikan Pancasila sebagai landasan buat demokrasi yang mereka bangun, demokrasi yang unik, yang melestarikan kekuasaan mereka selama-

40 Wahid, KH Abdurrahman. Prisma Pemikiran Gus Dur. LKIS Pelangi Aksara, 2010. Lihat juga, Ridwan, Nur Khalik. Negara Bukan-Bukan. IRCiSoD, 2018.

41 Dengel, Holk H. Darul Islam dan Kartosuwirjo: Langkah Perwujudan Angan-Angan yang Gagal. Pustaka Sinar Harapan, 1995; Dijk, Cornelis. Darul Islam: Sebuah Pemberontakan. Pustaka Utama Grafiti, 1987.

42 Syukur, Abdul. Gerakan Usroh di Indonesia: Kasus Peristiwa Lampung 1989, 2001; Solahudin. The Roots of Terrorism in Indonesia: From Darul Islam to Jema'ah Islamiyah. NUS Press, 2013; Rahmat, M. Imdadun. Ideologi Politik PKS: dari Masjid Kampus ke Gedung Parlemen. LKiS, 2008. 
lamanya. Soekarno menyebutnya "demokrasi terpimpin," ${ }^{43}$ sementara Soeharto menyebutnya "demokrasi Pancasila."

Dalam struktur negara Indonesia, Pancasila adalah bagian dari konstitusi, yang tertulis dalam Pembukaan UUD 1945. Soekarno menganggap Pancasila sebagai fondasi filosofis (philosophische grondslag) yang menyangga Indonesia sebagai negara. Bagi Soekarno sendiri, urutan-urutan sila tidaklah terlalu penting. Dalam pidatonya yang terkenal pada 1 Juni 1945 di depan panitia persiapan Indonesia merdeka, Soekarno meletakkan ketuhanan di urutan paling akhir, setelah kebangsaan, internasionalisme, mufakat, dan kesejahteraan sosial.44 Ketuhanan menjadi sila pertama muncul dalam rapat-rapat Panitia 9, yang bertugas merumuskan dasar negara. Tampaknya, kelompok Islam memainkan peran penting dalam rapat-rapat ini.

Pancasila dan hubungannya dengan agama di Indonesia telah menjadi obyek penelitian banyak sarjana. ${ }^{45}$ Salah satu kajian penting dan mendalam dilakukan oleh Ismatu Ropi, seorang sarjana dan dosen di Universitas Islam Negeri (UIN), Jakarta. Dalam bukunya, Religion and Regulation in Indonesia, Ropi menjelaskan tentang sejarah dan latarbelakang perdebatan seputar Pancasila dan upayaupaya memperebutkan tafsir tentangnya. Pada mulanya, ketika diterima sebagai dasar negara dan bagian dari konstitusi RI, Ketuhanan Yang Maha Esa dalam Pancasila bermaknacukup "netral.” Ia menjadi semacam perekat untuk semua golongan, khususnya kelompok agama-agama utama: Islam, Kristen, Hindu, dan Budha. Masing-masing merasa sila tersebut mewakili aspirasi religius mereka. Tak ada yang merasa diistimewakan dengan bunyi sila tersebut. ${ }^{46}$

Masalah baru muncul belakangan, khususnya ketika politik aliran dan politik identitas menguat menjelang Pemilu 1955 dan semakin memuncak memasuki tahun 1960an. Ketegangan ideologi antara Islam dan komunisme (PKI), dan antara Muslim dan non-Muslim, menjadi pendorong retaknya kepercayaan pada sila pertama Pancasila, khususnya di kalangan umat Islam. Perbincangan

43 Istilah "demokrasi terpimpin" diilhami oleh sila keempat Pancasila, yakni kerakyatan yang dipimpin oleh hikmah kebijaksanaan dalam permusyawaratan perwakilan.

44 Saafroedin Bahar, and Nannie Hudawati. Risalah Sidang Badan Penyelidik Usaha-Usaha Persiapan Kemerdekaan Indonesia (BPUPKI), Panitia Persiapan Kemerdekaan Indonesia (PPKI), 28 Mei 1945-22 Agustus 1945. Sekretariat Negara Republik Indonesia, 1998.

45 Lihat, misalnya Abdulgani, Roeslan. Pancasila: perjalanan sebuah ideologi. Gramedia Widiasarana Indonesia bekerja sama dengan FKN-Alumni GMNI, 1998; Pasha, Musthafa Kamal. Pancasila dalam tinjauan historis, yuridis dan filosofis. Citra Karsa Mandiri, 2002; Darmaputera, Eka. Pancasila and the Search for Identity and Modernity in Indonesian Society: A Cultural and Ethical Analysis. BRILL, 1988;Song, Seung-Won. Back to Basics in Indonesia? Reassessing the Pancasila and Pancasila State and Society, 1945--2007. BiblioBazaar, 2012; Intan, Benyamin Fleming. "Public Religion" and the Pancasila-Based State of Indonesia: An Ethical and Sociological Analysis. Peter Lang, 2006; Suryadinata, Leo. Pancasila and the Challenge of Political Islam: Past and Present. ISEAS-Yusof Ishak Institute, 2018.

46 Ropi, Ismatu. Religion and Regulation in Indonesia. Springer, 2017, h. 89. 
superficial mengenai sila pertama mulai bermunculan, dari penggunaan kata "tuhan” dan bukan "Allah," kata "esa” yang menodai keyakinan Kristen tentang trinitas, hingga keberadaan sila itu sendiri sebagai penghalang kelompok nonagama (ateis) untuk hidup damai di negeri ini. Singkatnya, Pancasila sebagai perekat dan pemersatu bangsa mulai dipertanyakan. Biang keladinya adalah sila pertama. ${ }^{47}$

Sebagian tokoh Kristen, seperti Helmut Rosin dan T.B. Simatupang merasa perlu turun tangan menjelaskan makna sila pertama itu. Menurut mereka, sila pertama dibuat untuk memayungi semua agama, dan bukan hanya satu agama saja. Karena itulah, istilah yang digunakan Soekarno bukan "tuhan” secara personal, tapi "ketuhanan." Menurut Rosin, penekanan istilah ini penting, bukan karena untuk menjawab tuduhan-tuduhan sebagian orang bahwa sila pertama bertentangan dengan doktrin trinitas, tapi juga untuk meyakinkan masyarakat Indonesia secara umum bahwa sila pertama tidak bertentangan dengan agama atau keyakinan apapaun yang ada di Indonesia, termasuk pemeluk Budha yang tak mengimani adanya Tuhan personal, maupun orangorang ateis yang tak meyakini keberadaan Tuhan. "Ini tampak seperti konsep yang kabur, tapi sebenarnya [dimaksudkan] untuk merangkul semua orang," tulis Rosin. ${ }^{48}$

Tokoh-tokoh Islam tidak tinggal diam. Setahun setelah Helmut Rosin menerbitkan bukunya tentang Pancasila, Hamka menulis semacam respon dalam sebuah buku berjudul Urat Tunggang Pantjasila. Di buku ini, Hamka terang-terangan menyanggah tafsir-tafsir anti-Islam tentang Pancasila. Dengan percaya diri, dia menegaskan bahwa Pancasila tidak bertentangan dengan Islam dan sila pertama tidak lebih dari terjemahan konsep Islam tentang tauhid. Tauhid atau monoteisme adalah doktrin sentral dalam Islam. ${ }^{49}$ Buku Hamka ini sekaligus menjadi jawaban terhadap Rosin dan Simatupang dari kelompok Kristen serta sanggahan kepada sebagian kaum Muslim yang mencurigai bahwa Pancasila adalah warisan Hindu.

Tafsir Hamka terhadap sila pertama cukup brilian. Secara literal, tauhid berarti esa atau tunggal. Inti ajaran tauhid adalah pengesaan terhadap Tuhan. Dengan kata lain, "Tuhan yang Maha Esa" adalah kata lain dari tauhid. Tafsir ini bukan hanya menepis keraguan sebagian kaum Muslim bahwa sila pertama terinspirasi

\footnotetext{
47 Ropi, Ismatu. "Ketuhanan Yang Maha Esa, The State and the Politics of Religious (In) Tolerance: Understanding Contemporary Religious Life Through Past Debates on the State-Religion Relationship." In Religion, Law and Intolerance in Indonesia, 166-191. Routledge, 2016.

48 Ropi, Ismatu. Religion and Regulation in Indonesia, h. 91.

49 Ibid, h. 90.
} 
dari tradisi Hindu, tapi juga -atau malah menjadi-- argumen bagi kaum Muslim bahwa sila pertama justru diambil dari ajaran Islam dan karenanya menjadi "milik" umat Islam, bukan agama-agama lain. Tak heran kalau tafsir ini kemudian diikuti oleh banyak tokoh Muslim lain dan diamini secara penuh oleh Haji Agus Salim, tokoh Muslim paling senior dan paling dihormati ketika itu..$^{50}$

Perang tafsir dan upaya "mengislamkan" Pancasila ini adalah isu penting yang tak banyak disadari orang dan memiliki dampak krusial bagi masa depan politik di Indonesia. Sila pertama Pancasila yang semula (setidaknya dalam bayangan Soekarno, sang pendiri) bersifat netral dan diproyeksikan sebagai payung bagi semua agama di Indonesia, diselewengkan maknanya menjadi sila yang diperuntukkan bagi kaum Muslim. Upaya presiden Soeharto mengembalikan makna Pancasila yang netral, khususnya sila pertama, tidak terlalu membuahkan banyak hasil. Bahkan langkahnya untuk memaksakan Pancasila sebagai satusatunya asas (Asas Tunggal) pada pertengahan tahun 1980an direspon secara keras oleh organisasi-organisasi Islam. ${ }^{51}$ Perlawanan terhadap rezim mendapatkan momentumnya dengan diberlakukannya Asas Tunggal. Kebijakan Orde Baru yang represif terhadap Islam perlahan-lahan menciptakan kebencian terhadap apa saja yang berbau Pancasila. ${ }^{52}$

Setelah era reformasi, upaya menafsirkan ulang Pancasila, seperti yang pernah dilakukan Hamka, dimulai kembali. Kali ini, perebutannya bukan hanya sebatas perdebatan tentang diksi dalam sila pertama, tapi bagaimana Pancasila secara keseluruhan dimaknai secara Islami dan bagaimana aturan-aturan Islam (syariat) bisa diterapkan di Indonesia tanpa menyalahi Pancasila. Demokrasi memberikan peluang kepada kaum Muslim menyalurkan aspirasi politik mereka. Sejak Pemilu 1999, kaum Muslim berusaha mengislamkan negeri ini lewat cara-cara yang demokratis. Sebagian melakukannya lewat partai politik, sebagian lainnya melakukannya lewat tekanan publik dan jaringan politik di birokrasi dan pemerintahan.

Jika sekarang kita melihat Pancasila memiliki citra yang "religius" dengan muatan tafsir Islam yang kental, itu adalah hasil perjuangan panjang para tokoh Islam, sejak Hamka pada era 1950an hingga tokoh-tokoh Islam kontemporer.

50 Ismail, Faisal. Islam, Politics and Ideology in Indonesia: A Study of the Process of Muslim Acceptance of the Pancasila. McGill University, 1995.

51 Harun, M. Shaleh, and Abdul Munir Mulkhan. Latar Belakang Ummat Islam Menerima Pancasila sebagai Asas Tunggal: Sebuah Kajian Informatif Pandangan NU-Muhammadiyah. Aquarius, 1986; Noer, Deliar. Islam, Pancasila dan Asas Tunggal. Yayasan Perkhidmatan, 1983.

52 Saleh, Hasanuddin M. HMI dan Rekayasa Asas Tunggal Pancasila. Kelompok Studi Lingkaran, 1996. 
Keberhasilan memaknai Pancasila menjadi dasar yang religius juga tak lepas dari peran lembaga-lembaga Islam yang ada di pemerintahan, seperti kementerian agama, peradilan agama, dan lembaga-lembaga semi-pemerintah seperti Majelis Ulama Indonesia (MUI). Pembicaraan tentang peran lembaga-lembaga Islam ini perlu pembahasan terpisah. Yang perlu diperhatikan di sini adalah bahwa Pancasila yang kita kenal sekarang sangat sarat dengan muatan agama. Sila pertama yang semula bersifat "netral" yang oleh tokoh-tokoh nasionalis bahkan dibayangkan bisa diterima oleh kaum ateis, kini menjadi satu tafsir. Hampir tidak ada tempat bagitafsir agnostik dan apalagi ateistik untuk sila pertama.

\section{Pasal-Pasal Religius}

Pancasila bukanlah satu-satunya isu yang berpotensi menjadi "masalah" dalam hubungan agama dan politik di Indonesia. Patut selalu diingat bahwa sebagian (besar) pendiri republik adalah orang-orang beriman yang menganggap agama sebagai sesuatu yang penting, bukan hanya sebagai panduan untuk setiap orang secara individu, tapi juga sebagai pegangan bagi terlaksananya pemerintahan. Kelompok nasionalis yang selalu digambarkan sebagai "orang-orang sekular" dan "liberal" seperti Soekarno, Soepomo, Syahrir, dan Mohammad Yamin, sesungguhnya adalah tokoh yang peduli pada agama. Mereka menganggap agama sebagai sesuatu yang penting dan menjadi bagian dari tradisi Indonesia yang tidak bisa diabaikan. Beberapa kaum nasionalis seperti Hatta bahkan seorang yang cukup religius dan rajin menjalankan ibadah. Karena itu, agama bukanlah sesuatu masalah untuk dimasukkan menjadi bagian dari konstitusi.

Jangan heran kalau kata "agama" bertaburan di sekujur konstitusi kita. Setidaknya 13 kali kata "agama" disebut dalam UUD 1945.53 Bandingkan dengan konstitusi Amerika Serikat di mana kata "religion" cuma disebut sekali, yakni di Amandemen Pertama. ${ }^{54}$ Atau bandingkan dengan konstitusi Perancis yang cuma disebut 3 kali. ${ }^{55}$ Dari beberapa isu menyangkut agama yang disebut di konstitusi RI, setidaknya ada tiga pasal yang berpotensi "bermasalah" atau setidaknya menjadi bahan perdebatan dalam perbincangan tentang hubungan agama dan politik, yakni Pasal 9 tentang presiden, Pasal 28J tentang kebebasan, dan Pasal 31 tentang sains dan teknologi.

53 UUD 1945 \& Perubahannya. Bmedia, 2016.

54 Us Constitution: Declaration of Independence, Bill of Rights, \& Amendments. Createspace Independent Pub, 2014.

55 French Constitution Of 1791. CreateSpace Independent Publishing Platform, 2018. 
Pasal 9 mengatur tentang sumpah yang harus dijalani seseorang ketika ia dilantik menjadi presiden. Konstitusi ini menegaskan sumpah itu harus dijalankan secara agama (baik Islam, Kristen, maupun yang lainnya). Intinya adalah beragama. Lebih tegas lagi, pasal ini mengatur bahwa sumpah itu harus dilafalkan dengan "demi Allah saya bersumpah...” yang mengindikasikan bias agama Ibrahimi yang sangat kuat, khususnya Islam. Pasal ini bukan hanya tidak memberi tempat pada agama-agama non-Ibrahimi (Hindu, Budha, Konghucu, dll), tapi secara tegas menolak ateisme. Dengan kata lain, secara konstitusional, seorang ateis tidak mungkin menjadi seorang presiden.

Pasal 28J Ayat 2 berbunyi: "Dalam menjalankan hak dan kebebasannya, setiap orang wajib tunduk kepada pembatasan yang ditetapkan dengan undang-undang dengan maksud semata-mata untuk menjamin pengakuan serta penghormatan atas hak dan kebebasan orang lain dan untuk memenuhi tuntutan yang adil sesuai dengan pertimbangan moral, nilai-nilai agama, keamanan, dan ketertiban umum dalam suatu masyarakat demokratis." Pasal ini memasukkan agama sebagai salah satu pembatas bagi kebebasan. Problem yang akan muncul dari pasal ini adalah nilainilai agama yang bersifat irasional dan subyektif. Jika ada perilaku bebas yang dianggap bertentangan dengan nilai-nilai agama, serta-merta akan dibatasi atas nama konstitusi. Pasal ini dengan mudah digunakan untuk menolak LGBT, misalnya, dengan alasan bahwa hak/kebebasan LGBT bertentangan dengan nilai-nilai agama.

Pasal 31 memiliki lima ayat, dua di antaranya bermasalah dan bisa menjadi sumber perdebatan tentang intoleransi dan diskriminasi. Ayat 2 berbunyi: "Pemerintah mengusahakan dan menyelenggarakan satu sistem pendidikan nasional, yang meningkatkan keimanan dan ketakwaan serta akhlak mulia dalam rangka mencerdaskan kehidupan bangsa, yang diatur dengan undang-undang." Sedangkan ayat 5 berbunyi: "Pemerintah memajukan ilmu pengetahuan dan teknologi dengan menjunjung tinggi nilai-nilai agama dan persatuan bangsa untuk kemajuan peradaban serta kesejahteraan umat manusia." Dua ayat ini adalah hasil amandemen keempat yang dilakukan pada 2002. Sejak diumumkan, ayat 2 telah menjadi perdebatan panjang di kalangan pendidik. Berdasarkan ayat ini, tujuan pendidikan bukanlah memperoleh ilmu pengetahuan tapi peningkatan keimanan, ketakwaan, serta akhlak yang mulia, yang semuanya adalah idiom agama (Islam). Ayat ini berpotensi menjadi penghambat paling utama sulitnya menerapkan pengajaran ilmu pengetahuan yang benar di sekolah-sekolah. 
Ayat 5 adalah pelengkap dari ayat 2, yang intinya membatasi pergerakan ilmu pengetahuan dan teknologi. Dalam dua ayat ini, Iptek harus tunduk pada nilianilai agama dan tidak boleh bertentangan dengan ajaran agama. Implikasi tidak langsung dari keberadaan ayat ini adalah sikap diskriminatif terhadap para ilmuwan yang sepenuhnya taat pada prinsip-prinsip ilmiah tapi mengabaikan ajaran agama (misalnya: teori evolusi, asal-usul alam raya, dll). Ilmuwan yang tidak tunduk pada ajaran agama akan mengalami diskriminasi, atau paling tidak mengalami tekanan dari kolega mereka yang religius atau dari masyarakat umum yang tunduk pada agama.

\section{UU Penodaan Agama}

UU Penodaan agama adalah aturan yang paling bermasalah dalam sejarah hubungan agama dan negara di Indonesia. Sejak disahkan menjadi UU pada 1969, UU Penodaan Agama telah memakan banyak korban. Ironisnya, UU ini banyak digunakan setelah era Reformasi, ketika kebebasan berkeyakinan dan kebebasan berekspresi seharusnya dijunjung tinggi. Studi Melissa A. Croach tentang UU ini menunjukkan bahwa selama masa Orde Baru, UU hanya melahirkan kurang dari 10 kasus, tapi sejak 1998, UU ini telah menghasilkan lebih dari 35 kasus dan mengirim lebih dari 120 orang ke penjara atas tuduhan menghina atau melecehkan agama. ${ }^{56} \mathrm{UU}$ penodaan agama adalah produk lama yang tak hanya ada di Indonesia. Di beberapa negara maju, termasuk di Eropa, UU semacam ini pernah ada namun sudah ditinggalkan, atau kalaupun masih ada, penggunaannya sudah dihentikan.

Di Indonesia sendiri, UU ini merupakan respon kaum beragama, umat Islam khususnya, terhadap kelompok komunis pada 1960an. Sebelum menjadi UU, pasal penodaan agama adalah sebuah keputusan pemerintah yang dikeluarkan oleh Presiden Soekarno. UU ini lengkapnya bernama Penetapan Presiden Republik Indonesia Nomor 1/PNPS Tahun 1965 tentang Pencegahan Penyalahgunaan dan/atau Penodaan Agama. Secara singkat, lebih dikenal dengan nama "UU Penodaan Agama." Pada era 1960an, komunisme cukup dominan dalam panggung politik Indonesia. Sebagian kaum komunis dikenal tak beragama atau cenderung anti-agama. Sebagian mereka mengekspresikan ketidaksukaannya dengan cara menjelek-jelekkan atau menghina ajaran agama, khususnya Islam. Perilaku ini membuat kaum Muslim marah dan kerap terjadi

56 Crouch, Melissa A. "Law and Religion in Indonesia: The Constitutional Court and the Blasphemy Law." Asian Journal of Comparative Law Vol. 7, Issue 1, 2012, h. 12. Baca juga, Rumadi. Delik Penodaan Agama dan Kehidupan Beragama dalam RUU KUHP. Yayasan Tifa, 2007. 
konflik. Untuk menertibkan dan mengantisipasi konflik yang lebih besar, beberapa tokoh agama mendesak presiden Soekarno mengeluarkan aturan.

Ketika Soeharto menggantikan Soekarno, peraturan itu tidak dihapus, tapi malah justru diperkuat dengan menjadikannya UU pada 1969. Alasan lain mengapa aturan ini diperkuat, selain karena ancaman PKI, juga karena munculnya aliran-aliran keagamaan (atau kepercayaan), yang dianggap bisa menodai ajaran agama-agama mayoritas, khususnya Islam. Di zaman Soeharto, UU ini tak terlalu banyak digunakan karena Soeharto menerapkan kebijakan yang keras bagi pengacau stabilitas sosial dan politik. Sikapnya yang tegas terhadap orang atau kelompok yang memainkan isu SARA, membuat orang takut berbicara dan mengungkapkan pandangannya. Salah satu isu yang paling menghebohkan yang terkait langsung dengan UU ini adalah kasus yang menimpa Arswendo Atmowiloto, seorang wartawan, yang membuat angket (survey) popularitas tokoh-tokoh dunia. Dalam angket yang ia sebarkan lewat tabloid Monitor yang dipimpinnya itu, Nabi Muhammad menempati urutan ke-11, persis di bawah dirinya yang menempati urutan ke-10. Karena angket ini, Arswendo didemo dan pemerintah tak ragu sedikitpun untuk mengirimnya ke penjara. ${ }^{57}$

Sejak Reformasi, UU Penodaan Agama seringkali digunakan untuk mengancam, menuduh, dan menyeret orang ke meja hijau. Salah satu kasus paling serius terkait UU ini adalah peristiwa yang menimpa mantan Gubernur DKI Jakarta, Basuki "Ahok" Tjahaya Purnama. Ahok didakwa menistakan agama, karena mengemukakan pandangan pribadinya yang sepenuhnya valid dan berdasarkan fakta, yakni ada sebagian Muslim yang menggunakan ayat al-Quran (al-Maidah 51) untuk melarang non-Muslim menjadi pemimpin. Karena pernyataannya itu, Ahok dikecam, didemo dan dikriminalisasi. Untuk meredam massa, ia pun diganjar dua tahun penjara.

\section{Aturan Rumah Ibadah}

Aturan tentang pendirian rumah ibadah adalah ketentuan lain yang menjadi akar-akar legal diskriminasi dan intoleransi yang terjadi di Indonesia. Aturan berbentuk Surat Keputusan Bersama (SKB) ini dikeluarkan oleh dua kementerian, yakni Kementrian Agama dan Kementrian Dalam Negeri RI pada 1969. Seperti bisa dipahami dari namanya, surat ini merupakan respon

57 Djafar, Alamsyah M. (In)toleransi - Memahami Kebencian \& Kekerasan Atas Nama Agama. Elex Media Computindo, 2018, h. 231-232. 
atas keresahan masyarakat seputar pendirian rumah ibadah yang mereka anggap tak terkontrol. Tapi, dalam praktiknya, aturan ini sesungguhnya adalah respon dari ketakutan kaum Muslim terhadap isu Kristenisasi dan maraknya pendirian gereja di Indonesia. ${ }^{58}$ Sejak tahun 1960an, isu Kristenisasi memang marak berkembang di Indonesia. Respon kaum Muslim umumnya negatif dan berusaha meminta pemerintah untuk turun tangan mengatasinya.

Pada mulanya, sebagian kaum Muslim cukup puas dengan aturan soal pendirian rumah ibadah ini. Puluhan rencana pendirian gereja dibatalkan dan ratusan lainnya menjadi isu menggantung, yang kerap menjadi pemicu konflik dan ketegangan di masyarakat. Kaum Kristen yang tak memperoleh izin mendirikan rumah ibadah kerap melakukan kegiatan ibadah di rumah-rumah penduduk, yang kemudian memicu persoalan lain yang terkait izin penggunaan rumah sebagai kegiatan ibadah.

Karena banyaknya kasus-kasus izin penyelenggaraan ibadah, pada 2006, pemerintah sekali lagi mengeluarkan aturan yang menguatkan SKB Rumah Ibadah. Alih-alih mempermudah izin dan melonggarkan aturan pendirian rumah ibadah, Peraturan Bersama ini malah mempersulitnya. Dalam peraturan baru ini, setiap warga yang berencana mendirikan rumah ibadah harus mengumpulkan dukungan 90 orang ber-KTP dan memiliki izin berupa surat pernyataan tertulis dari 60 warga di sekeliling lokasi rencana pendirian serta disetujui oleh kepala desa/wilayah. Selain itu, dia juga harus mengumpulkan surat rekomendasi dari Kementerian Agama dan dari Forum Kerukunan Umat Beragama (FKUB) setempat.

\section{Kesimpulan}

Intoleransi beragama dan diskriminasi yang menguat akhir-akhir ini di Indonesia bisa terjadi karena beragam sebab. Ia bisa terjadi karena masalah ekonomi, masalah sosial, maupun karena gesekan budaya. Namun, satu hal yang pasti dan jarang diperhatikan orang adalah bahwa intoleransi kerap dipicu oleh kebijakan dan UU yang dikeluarkan pemerintah. Lebih fundamental lagi, intoleransi dan diskriminasi memiliki akar yang kuat dalam konstitusi dan aturan-aturan legal kita. Pasal-pasal dalam konstitusi yang semula diniatkan untuk merangkul dan memayungi semua agama, misalnya, memiliki dampak lain yang justru bertolak belakang dari semangat awal ketika pasal-pasal itu dibuat. Aturan-aturan yang

58 Nurkholis, Ahmad. Merajut Damai dalam Kebinekaan. Elex Media Komputindo, 2017. 
dibuat untuk perbaikan negara, kemudian justru dipakai sebagai instrumen untuk menekan, mendiskriminasi, dan mengkriminalisasi orang.

Sikap-sikap intoleran dan diskriminatif tidak akan memiliki relevansi jika tidak ada landasan hukum yang mendukungnya.Berbagai perilaku intoleran di tengah masyarakat menjelmamenjadi isu besar dan berkembang menjadi persoalan nasional karena ada landasan legal yang membuatnya demikian. Kasus yang menimpa Ahok adalah contoh paling jelas bagaimana sebuah pernyataan dipolitisasi dan dijadikan kasus "penistaan" yang melanggar UU. Jika tak ada UU Penodaan Agama, sangat mungkin tak akan ada kriminalisasi terhadap Ahok, tak akan ada demo 212 dan tak akan ada kebencian yang menyesaki ruang-ruang publik selama Pilkada DKI 2016-2017.

Sikap intolerandan diskriminatif ada dalam setiap masyarakat. Namun, sikapsikapitu tak akan bisa berkembang jika tak didukung oleh perangkat legal. UU dan konstitusi Indonesia sarat dengan pasal-pasal dan aturan yang rentan dijadikan rujukan perilaku intoleransi dan diskriminasi. Selama tidak ada upaya untuk mengubahnya, lewat amandemen atau pengujian yudisial, selama itu pula perilaku intoleransi dan diskriminasi memiliki pijakan kokoh dan sulit diberantas.

\section{Daftar Pustaka}

Abdulgani, Roeslan. Pancasila: perjalanan sebuah ideologi. Gramedia Widiasarana Indonesia bekerja sama dengan FKN-Alumni GMNI, 1998.

Azra, Azyumardi. Indonesia, Islam, and Democracy: Dynamics in a Global Context. Equinox Publishing, 2006.

Bahar, Saafroedin and Hudawati, Nannie. Risalah Sidang Badan Penyelidik Usaha-Usaha Persiapan Kemerdekaan Indonesia (BPUPKI), Panitia Persiapan Kemerdekaan Indonesia (PPKI), 28 Mei 1945-22 Agustus 1945. Sekretariat Negara Republik Indonesia, 1998.

Benda, Harry Jindrich. The Crescent and the Rising Sun: Indonesian Islam Under the Japanese Occupation, 1942-1945. Institute of Pacific Relations, New York, 1958.

Bruinessen, Martin van. Contemporary Developments in Indonesian Islam: Explaining the "Conservative Turn." Institute of Southeast Asian Studies, 2013.

Burhanudin, Jajat, and Kees van Dijk. Islam in Indonesia: Contrasting Images and Interpretations. Amsterdam University Press, 2013. 
Crouch, Melissa A. "Law and Religion in Indonesia: The Constitutional Court and the Blasphemy Law." Asian Journal of Comparative Law Vol. 7, Issue $1,2012$.

Darmaputera, Eka. Pancasila and the Search for Identity and Modernity in Indonesian Society: A Cultural and Ethical Analysis. BRILL, 1988.

Dengel, Holk H. Darul Islam dan Kartosuwirjo: Langkah Perwujudan Angan-Angan yang Gagal. Pustaka Sinar Harapan, 1995.

Dijk, Cornelis. Darul Islam: Sebuah Pemberontakan. Pustaka Utama Grafiti, 1987.

Djafar, Alamsyah M. (In)toleransi - Memahami Kebencian $\mathcal{E}$ Kekerasan Atas Nama Agama. Elex Media Computindo, 2018.

Effendy, Bahtiar. Islam and the State in Indonesia. ISEAS Series on Islam. Singapore: Institute of Southeast Asian Studies, 2003.

Fealy, Greg, and Sally White. Expressing Islam: Religious Life and Politics in Indonesia. Institute of Southeast Asian Studies, 2008.

Harun, M. Shaleh, and Abdul Munir Mulkhan. Latar Belakang Ummat Islam Menerima Pancasila sebagai Asas Tunggal: Sebuah Kajian Informatif Pandangan NU-Muhammadiyah. Aquarius, 1986.

Hefner, Robert W. Civil Islam: Muslims and Democratization in Indonesia. Princeton University Press, 2011.

Intan, Benyamin Fleming. "Public Religion" and the Pancasila-Based State of Indonesia: An Ethical and Sociological Analysis. Peter Lang, 2006.

Ismail, Faisal. Islam, Politics and Ideology in Indonesia: A Study of the Process of Muslim Acceptance of the Pancasila. McGill University, 1995.

Kersten, Carool. Islam in Indonesia: The Contest for Society, Ideas and Values. Oxford University Press, 2015.

Mietzner, Marcus. Military Politics, Islam, and the State in Indonesia: From Turbulent Transition to Democratic Consolidation. Institute of Southeast Asian Studies, 2009.

Mujani, Saiful. Muslim Demokrat: Islam, Budaya Demokrasi, dan Partisipasi Politik di Indonesia Pasca Orde Baru. Gramedia Pustaka Utama, 2007.

Noer, Deliar. Islam, Pancasila dan Asas Tunggal. Yayasan Perkhidmatan, 1983.

Nurkholis, Ahmad. Merajut Damai dalam Kebinekaan. Elex Media Komputindo, 2017.

Pasha, Musthafa Kamal. Pancasila dalam tinjauan historis, yuridis dan filosofis. Citra Karsa Mandiri, 2002.

Platzdasch, Bernhard. Islamism in Indonesia: Politics in the Emerging Democracy. Institute of Southeast Asian Studies, 2009.

Rahmat, M. Imdadun. Ideologi Politik PKS: dari Masjid Kampus ke Gedung Parlemen. LKiS, 2008. 
Ridwan, Nur Khalik. Negara Bukan-Bukan. IRCiSoD, 2018.

Ropi, Ismatu. "Ketuhanan Yang Maha Esa, The State and the Politics of Religious (In) Tolerance: Understanding Contemporary Religious Life Through Past Debates on the State-Religion Relationship," dalam Religion, Law and Intolerance in Indonesia, 166-191. Routledge, 2016.

Ropi, Ismatu. Religion and Regulation in Indonesia. Springer, 2017.

Rumadi. Delik Penodaan Agama dan Kehidupan Beragama dalam RUU KUHP. Yayasan Tifa, 2007.

Saleh, Hasanuddin M. HMI dan Rekayasa Asas Tunggal Pancasila. Kelompok Studi Lingkaran, 1996.

Solahudin. The Roots of Terrorism in Indonesia: From Darul Islam to Jema'ah Islamiyah. NUS Press, 2013.

Song, Seung-Won. Back to Basics in Indonesia? Reassessing the Pancasila and Pancasila State and Society, 1945-2007. BiblioBazaar, 2012.

Suryadinata, Leo. Pancasila and the Challenge of Political Islam: Past and Present. ISEAS-Yusof Ishak Institute, 2018.

Syukur, Abdul. Gerakan Usroh di Indonesia: Kasus Peristiwa Lampung 1989, 2001.

Wahid, KH Abdurrahman. Prisma Pemikiran Gus Dur. LKIS Pelangi Aksara, 2010. 